\title{
Evaluation of Bioactive Properties of $\alpha$ and $\beta$ Wollastonite Bioceramics Soaked in a Simulated Body Fluid
}

\author{
Luis A. Núñez-Rodríguez¹, Martín A. Encinas-Romero²*, Agustín Gómez-Álvarez², \\ Jesús L. Valenzuela-García ${ }^{2}$, Guillermo C. Tiburcio-Munive ${ }^{2}$ \\ ${ }^{1}$ Posgrado en Ciencias de la Ingeniería: Ingeniería Química, Universidad de Sonora, Hermosillo, México \\ ${ }^{2}$ Departamento de Ingeniería Química y Metalurgia, Universidad de Sonora, Hermosillo, México \\ Email: *martin.encinas@unison.mx
}

How to cite this paper: Núñez-Rodríguez, L.A., Encinas-Romero, M.A., Gómez-Álvarez, A., Valenzuela-García, J.L. and TiburcioMunive, G.C. (2018) Evaluation of Bioactive Properties of $\alpha$ and $\beta$ Wollastonite Bioceramics Soaked in a Simulated Body Fluid. Journal of Biomaterials and Nanobiotechnology, 9, 263-276.

https://doi.org/10.4236/jbnb.2018.93015

Received: April 9, 2018

Accepted: June 29, 2018

Published: July 4, 2018

Copyright $\odot 2018$ by authors and Scientific Research Publishing Inc. This work is licensed under the Creative Commons Attribution International License (CC BY 4.0).

http://creativecommons.org/licenses/by/4.0/

\begin{abstract}
Dense natural wollastonite bioceramics $\left(\mathrm{CaSiO}_{3}\right)$ were prepared by a sintering method, varying the pressing load and sintering temperature, in order to obtain different phases of wollastonite, and different physical properties in the materials. The products were characterized by TGA-DTA, XRD, FT-IR, SEM-EDS, TEM and XPS techniques. The results indicate the presence of two polymorphic phases of wollastonite, the $\beta$-wollastonite and $\alpha$-wollastonite with a transition temperature of the $\beta$ phase to $\alpha$ phase at approximately $1250^{\circ} \mathrm{C}$. These materials were soaked in a simulated body fluid (SBF) during 1,2 and 3 weeks, to study their solubility and bioactivity. The effect of different wollastonite phases on the solubility of $\mathrm{Ca}$ and $\mathrm{Si}$, as well as the capacity of producing layers of "newly formed apatite" on the surfaces of these materials in SBF solution were analyzed.
\end{abstract}

\section{Keywords}

Bioceramics, Wollastonite, Simulated Body Fluid, Bioactivity

\section{Introduction}

A biomaterial is a substance designed to be implanted or incorporated into a living system. Biomaterials are implanted in order to replace and/or restore living tissues and their functions [1]-[6]. Biocompatibility is the ability of a substance to have an adequate response to the host in which it was implanted for its specific function [1]. This response includes resistance to blood coagulation, resistance to bacteriological colonization, and normal recovery without complica- 
tion [1]-[6]. Any biomaterial for bone substitution or repair must meet two main requirements: Have good mechanical strength and adequate porosity, which allows it to fulfill its function at the site of the injury and support the biological mechanisms of regeneration [4] [5]. Hydroxyapatite $\left(\mathrm{Ca}_{10}\left(\mathrm{PO}_{4}\right)_{6}(\mathrm{OH})_{2}\right)$, is a calcium phosphate ceramic of great interest in biomedical applications, due to the similarity of this compound with the material that makes up the bones. However, synthetic hydroxyapatite has poor mechanical properties, which is why it is mainly used to coat other materials with more resistant mechanical properties. One of the most important reinforcing minerals is wollastonite, a calcium silicate found in natural form with $\mathrm{CaSiO}_{3}$ molecular formula, which is a biocompatible material with bioactive characteristics, similar to those of hydroxyapatite, which has been used with high efficiency as a reinforcement phase for many composite materials. Nevertheless the wollastonite as an individual phase, has been shown to have an efficient mechanical behavior, as well as excellent bioactive properties, which places it at the forefront, as an important bioceramic to be used in the form of powders or dense sintered materials, to repair injuries related to the human hard tissues. On the other hand, wollastonite presents two different crystallographic phases, the $\beta$-wollastonite phase and the $\alpha$-wollastonite phase; both have different properties and qualities, which must be studied to find their most efficient applications in the environment of the hard tissues [6]-[12]. Likewise, natural wollastonite represents a mineral of great regional importance, since in Hermosillo, Sonora, Mexico the mining company "Minera Roca Rodando S. de R.L. de C.V.", performs operations in the deposit "Pilares", producing wollastonite of high purity, which could be used directly as a biomaterial in various clinical applications. For this reason, this research work addresses the study of the solubility and bioactivity of sintered materials of natural wollastonite, which were produced under different sintering conditions, to achieve with it products with different properties, in order to propose an alternative bioceramic material, to be used efficiently as an implant in bone tissue lesions.

\section{Experimental}

\subsection{Preparation of Wollastonite Sintered Bioceramics}

The wollastonite sintered materials were prepared using $0.5 \mathrm{~g}$ of high purity natural wollastonite $\left(\mathrm{CaSiO}_{3}\right.$, NYAD M200 Minera Roca Rodando S. de R.L. de C.V., Deposit Pilares, Hermosillo, Sonora, Mexico), with $98.25 \%$ purity using a sintering technique. The chemical analysis and the typical properties of wollastonite used in this study can be found elsewhere [13] [14] [15] [16]. For the sintering process $2 \mathrm{~g}$ of wollastonite in $5 \mathrm{~mL}$ of ethanol were ground for 30 minutes in a tungsten carbide ball mill Fritsch Pulverisette 6 planetary mill (Idar-Oberstein, Germany), at a speed of $200 \mathrm{rpm}$. The ground materials were dried at $120^{\circ} \mathrm{C}$ to remove the ethanol and obtain a fine powder. Cylindrical tablets were produced by uniaxial pressing of powders $(0.5 \mathrm{~g})$ into a $10 \mathrm{~mm}$ diameter die in a Carver 
press Hydraulic Unit 3912 (Carver, Wabash, IN) at a pressure of $70 \mathrm{MPa}, 220$ $\mathrm{MPa}$ and $500 \mathrm{MPa}$ for $5 \mathrm{~min}$. Sintering tests were carried out in a Thermolyne 46,100 high temperature furnace (Thermolyne, Dubuque, IA) at $1200^{\circ} \mathrm{C}$ and $1300^{\circ} \mathrm{C}$. The thermal process was developed at a heating rate of $2^{\circ} \mathrm{C} / \mathrm{min}$ from room temperature to the sintering temperature, with a dwell time of $5 \mathrm{~h}$ at the maximum temperature followed by cooling at $2^{\circ} \mathrm{C} / \mathrm{min}$.

\subsection{Evaluation of the Bioactive Properties of Wollastonite Sintered Bioceramics}

The bioactivity was evaluated by examining the new layer of apatite formed on the surface of the materials after immersion for 1, 2 and 3 weeks in $40 \mathrm{~mL}$ of a simulated body fluid solution (SBF), with ions concentration as reports in Table 1 , nearly equal to that of human blood plasma at $37^{\circ} \mathrm{C}$ [17]. After each evaluation period, the samples were taken out of the solution, washed with deionized water and dried at room temperature. The evaluation of the morphology and composition of the layers were carried out by SEM/EDS and XPS. For the determination of the changes in the concentration of $\mathrm{Ca}, \mathrm{P}$ and $\mathrm{Si}$ ions, as well as the $\mathrm{pH}$ changes of the SBF solution after soaking for each period of time, the following techniques were used: atomic absorption spectroscopy (for analyses of $\mathrm{Ca}$ and $\mathrm{Si}$ ), colorimetry (for analyses of $\mathrm{P}$ ) and $\mathrm{pH}$ measurement [17].

\subsection{Characterization Techniques}

To detect the transformations that occur in the materials with the modification of their temperature, the techniques of thermal gravimetric analysis (TGA), in combination with differential thermal analyses (DTA) were used. Both analyzes were developed in a simultaneous DSC-TGA analyzer equipment (TA Instruments SDT 2990, New Castle, DE). The heating interval was from room temperature to $1400^{\circ} \mathrm{C}$, at a speed of $10^{\circ} \mathrm{C} / \mathrm{min}$ with an air flow of $23 \mathrm{~cm}^{3} / \mathrm{min}$. XRD analyses were carried out by means of a Phillips X'PERT XRD diffractometer (Phillips Electronics, N.V. Eindhoven, The Netherlands), CuK $\alpha$ radiation was used $(40 \mathrm{~mA}, 40 \mathrm{kV})$. The $2 \Theta$ range was from $20^{\circ}$ to $80^{\circ}$ at a scanning speed of $1.2 \% \mathrm{~min}$. Morphological studies of the samples were performed using a JEOL SEM 5300 scanning electron microscope (JEOL, Tokyo, Japan), all the presented micrographs were obtained without any type of material coatings. For the determination of $\mathrm{Ca}$ and $\mathrm{Si}$ concentrations in the SBF solutions, an atomic absorption spectrometer (Perkin Elmer model Analyst 400, Waltham, MA) was used.

Table 1. Ion concentration of simulated body fluid (SBF) and human blood plasma $(\mathrm{mM}), \mathrm{pH}=7.4, \mathrm{~T}=37^{\circ} \mathrm{C}$.

\begin{tabular}{ccccccccc}
\hline \multicolumn{7}{c}{ Ion Concentration (mM) } \\
\hline & $\mathrm{Na}^{+}$ & $\mathrm{K}^{+}$ & $\mathrm{Mg}^{2+}$ & $\mathrm{Ca}^{2+}$ & $\mathrm{Cl}^{-}$ & $\mathrm{HCO}_{3}^{-}$ & $\mathrm{HPO}_{4}^{2-}$ & $\mathrm{SO}_{4}^{2-}$ \\
\hline SBF & 142.0 & 5.0 & 1.5 & 2.5 & 147.8 & 4.20 & 1.0 & 0.5 \\
Blood Plasma & 142.0 & 5.0 & 1.5 & 2.5 & 103.0 & 27.0 & 1.0 & 0.5 \\
\hline
\end{tabular}


For the determination of $\mathrm{P}$ concentration in the SBF solutions a spectrophotometer (Hach series DR-800, Loveland CO) was used. For analyses of pH-values in the SBF solution a $\mathrm{pH}$ meter (Cole-Parmer, Vernon Hills, IL) was used.

\section{Results and Discussion}

\subsection{Transformation of $\beta$-Wollastonite Phase to the $\alpha$-Wollastonite Phase}

In order to know the exact temperature at which the $\beta$-wollastonite phase is transformed into $\alpha$-wollastonite, the thermal analysis shown in Figure 1 was developed. This figure depicts the effect of the thermal treatment on the natural wollastonite as received from the mining company Roca Rodando S. de R.L. of C.V., which corresponds to the phase of $\beta$-wollastonite, as indicated by the X-ray diffraction pattern presented in Figure 2, according to JCPDS file 84-0654. The TGA and DTA traces show no apparent change in the whole thermal treatment range for wollastonite; however, the small thermal process around $1250^{\circ} \mathrm{C}$, it may be due to the transition process of $\beta$-wollastonite phase into the $\alpha$-wollastonite phase. To corroborate the above, the natural wollastonite ( $\beta$-wollastonite phase) was thermally treated up to $1300^{\circ} \mathrm{C}$ for 24 hours and then analyzed by the X-ray diffraction technique. Figure 3 shows the X-ray diffraction pattern for natural wollastonite treated at $1300^{\circ} \mathrm{C}$. In this figure it is observed how this diffraction pattern changed drastically when contrasting this with the diffraction pattern shown in Figure 2, which indicates that the material was completely transformed to the $\alpha$-wollastonite phase, according to JCDPS file 74-0874.

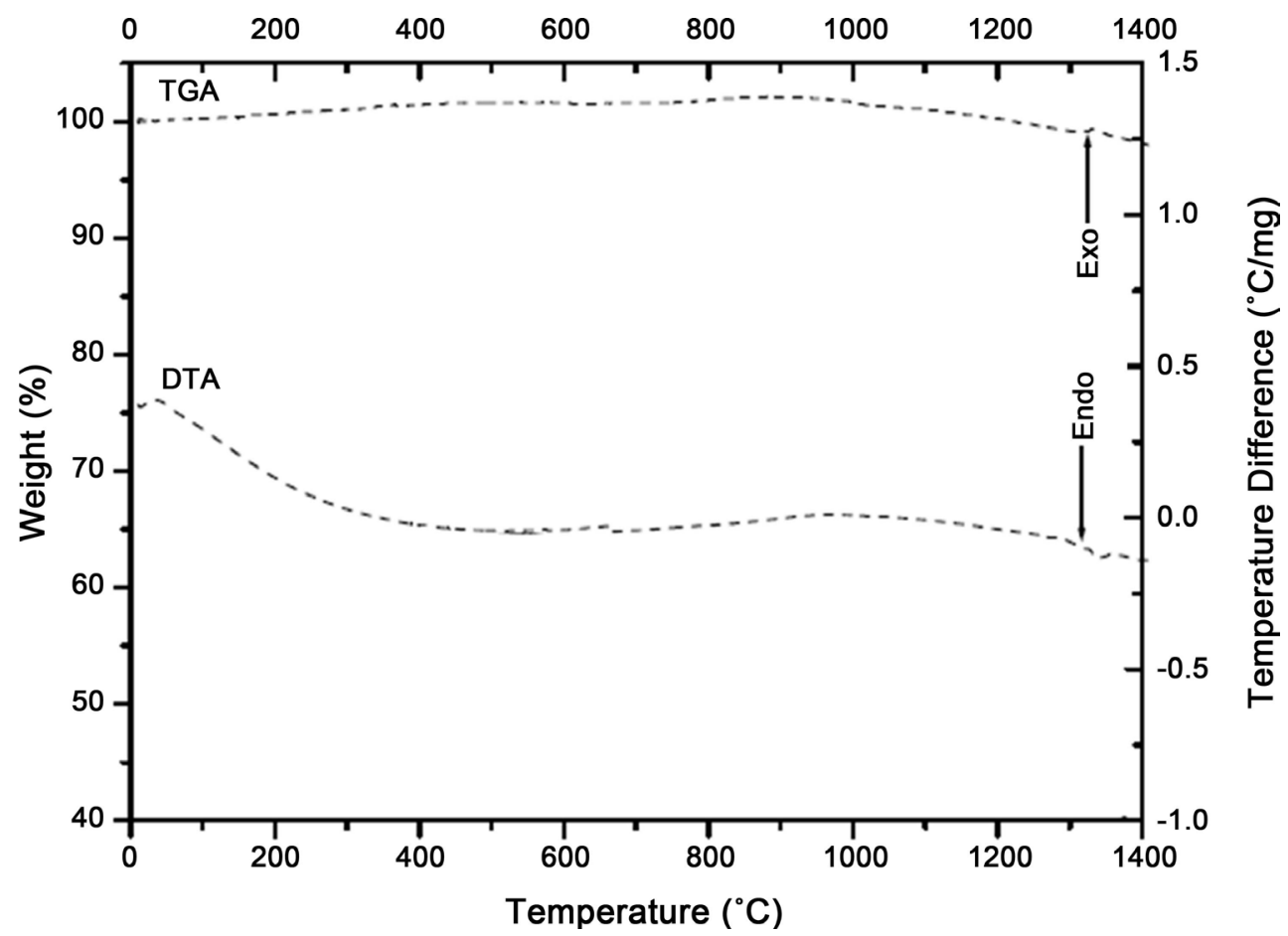

Figure 1. TGA/DTA traces for the natural wollastonite as received, thermally treated from room temperature to $1400^{\circ} \mathrm{C}$ at a heating rate of $10^{\circ} \mathrm{C} / \mathrm{min}$. 


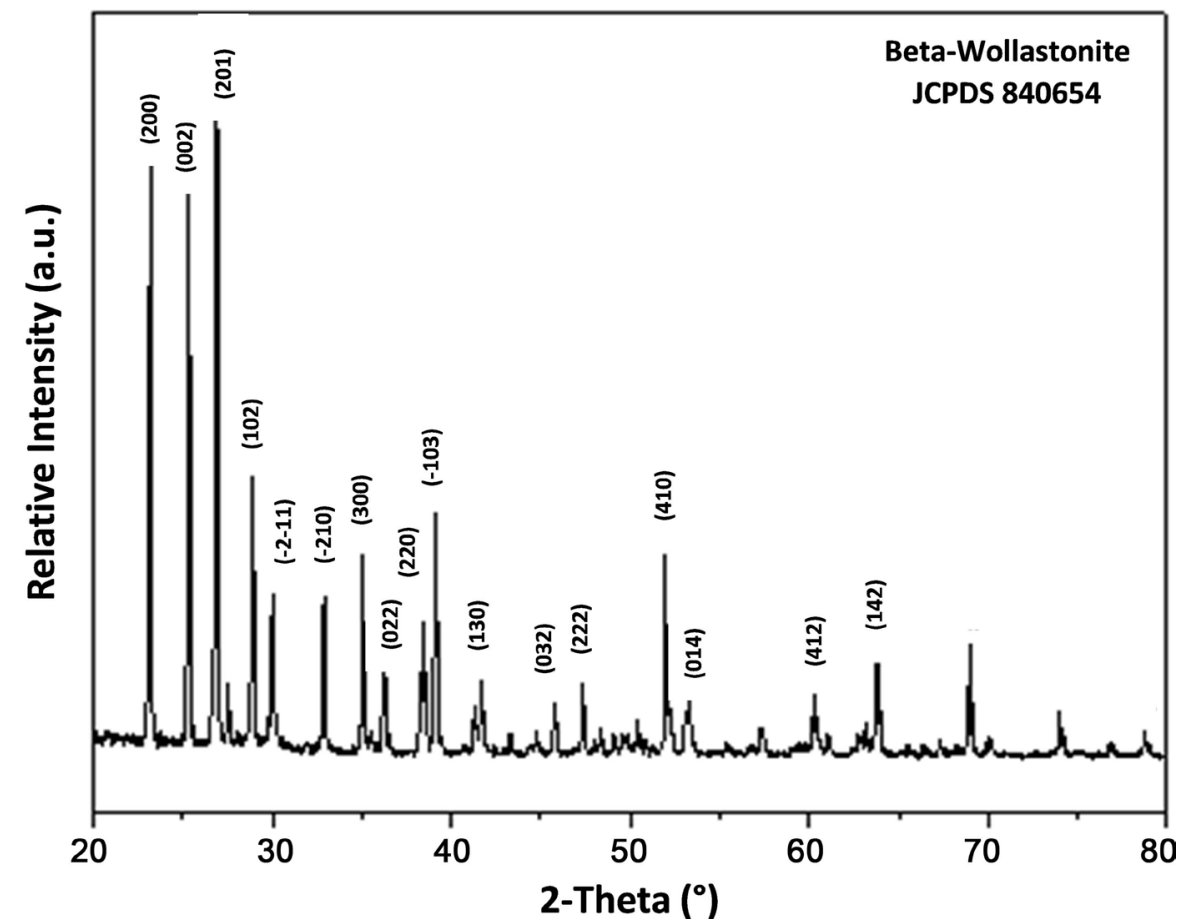

Figure 2. X-ray diffraction pattern for natural wollastonite as received.

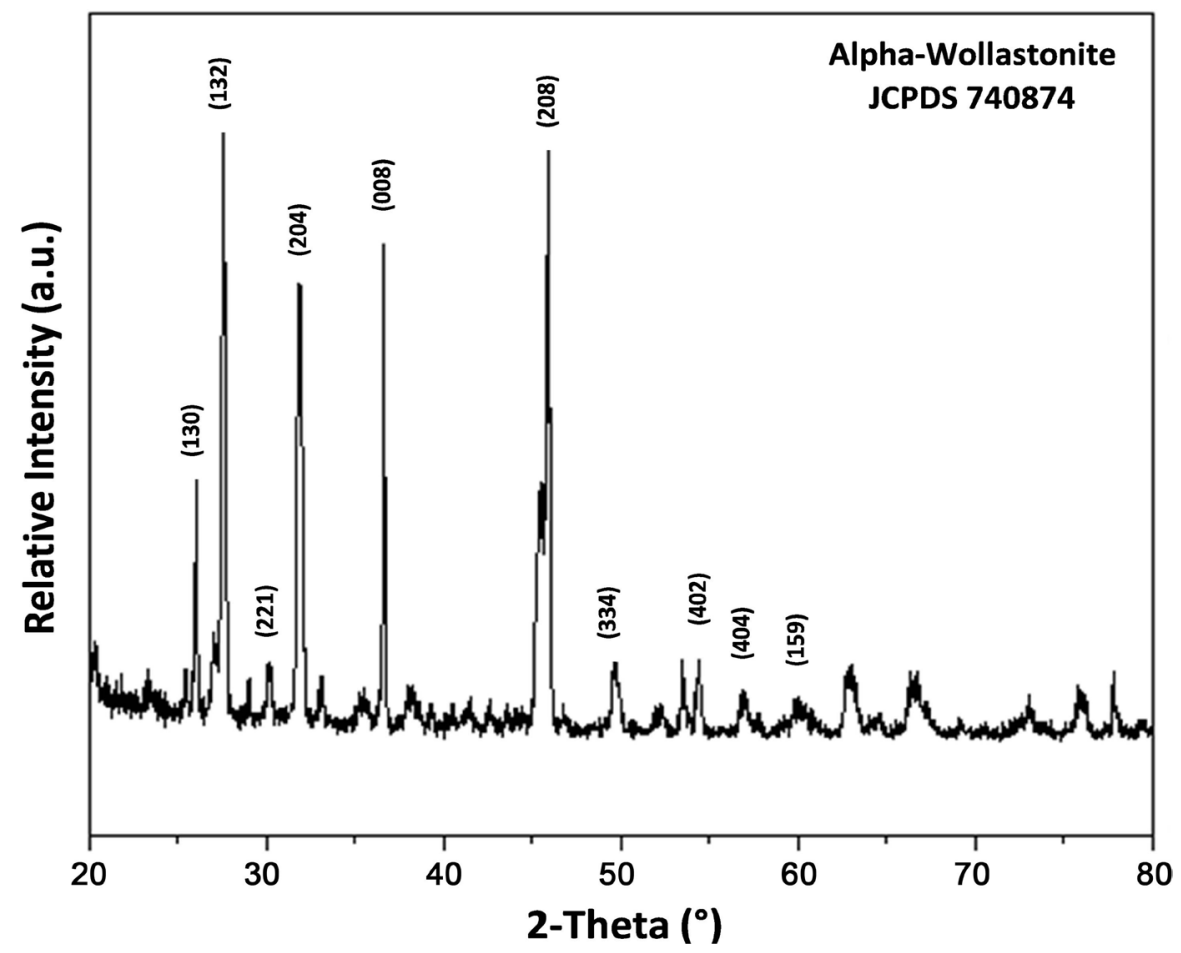

Figure 3. X-ray diffraction pattern for natural wollastonite thermally treated up to $1300^{\circ} \mathrm{C}$.

\subsection{Evaluation of Bioactive Properties of Wollastonite Sintered Bioceramics}

Figure 4 and Figure 5 show the scanning electron microscope (SEM) micrographs of the surfaces of the sintered materials at $1200^{\circ} \mathrm{C}$ and $1300^{\circ} \mathrm{C}$ respectively, after 

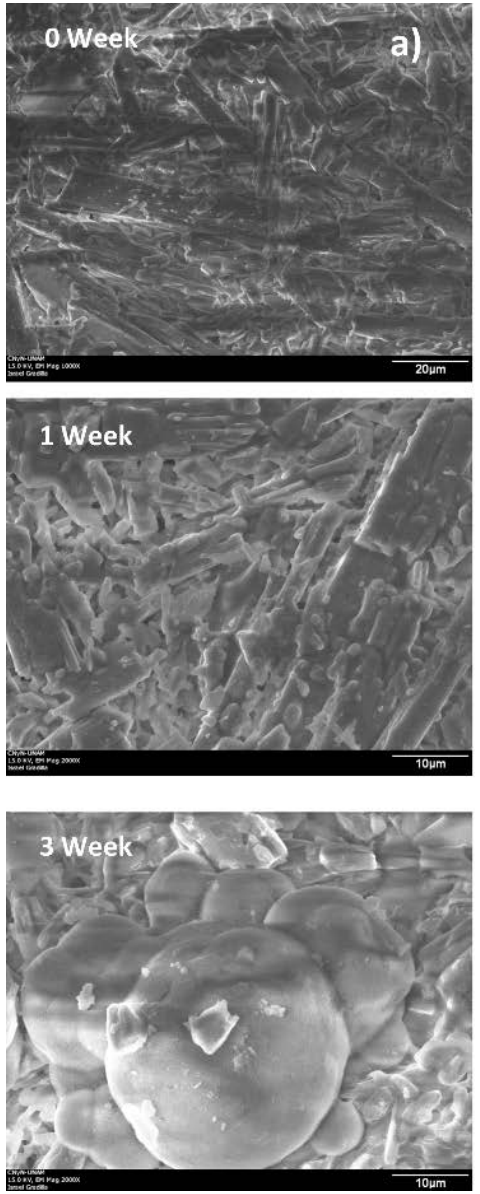
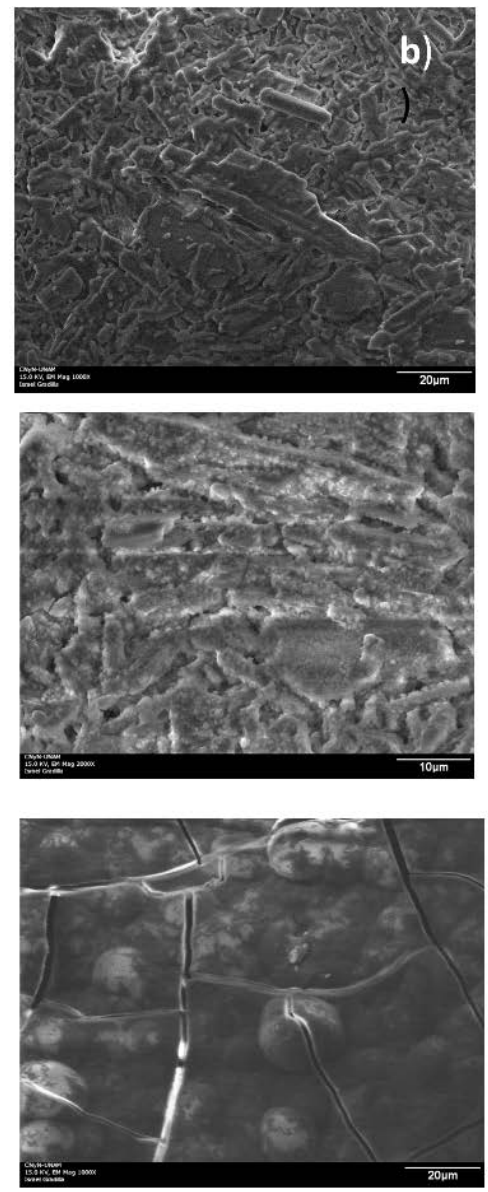
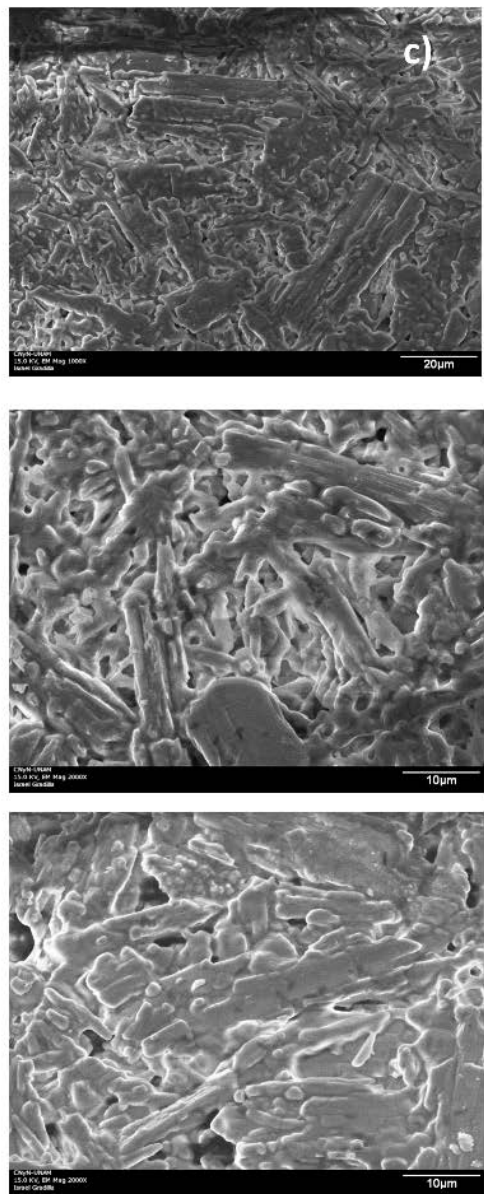

Figure 4. Scanning electron microscopy (SEM) micrographs of natural wollastonite sintered at $1200^{\circ} \mathrm{C}$, pressed at (a) $70 \mathrm{MPa},(\mathrm{b})$ $220 \mathrm{MPa}$ and (c) $500 \mathrm{MPa}$, soaked in SBF solution for 0, 1 and 3 weeks.
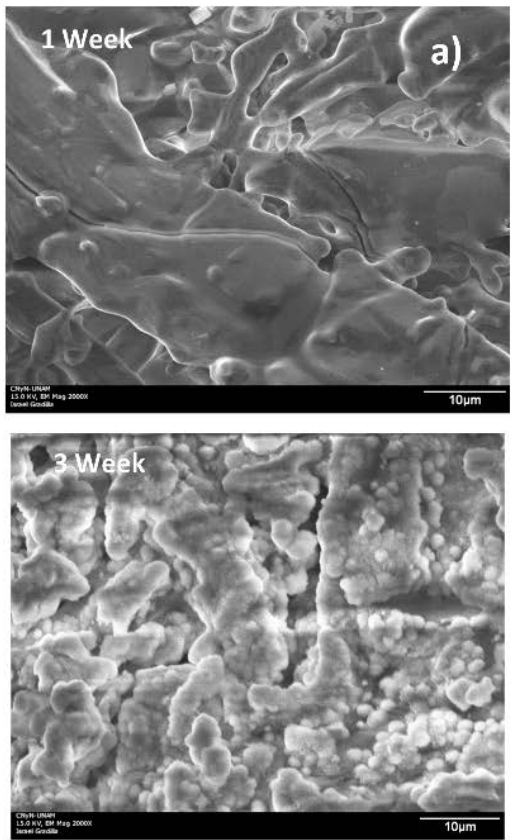
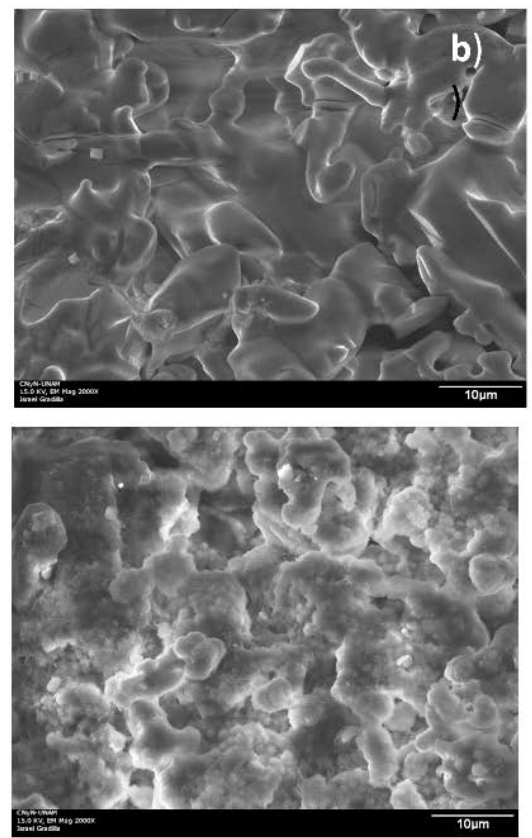
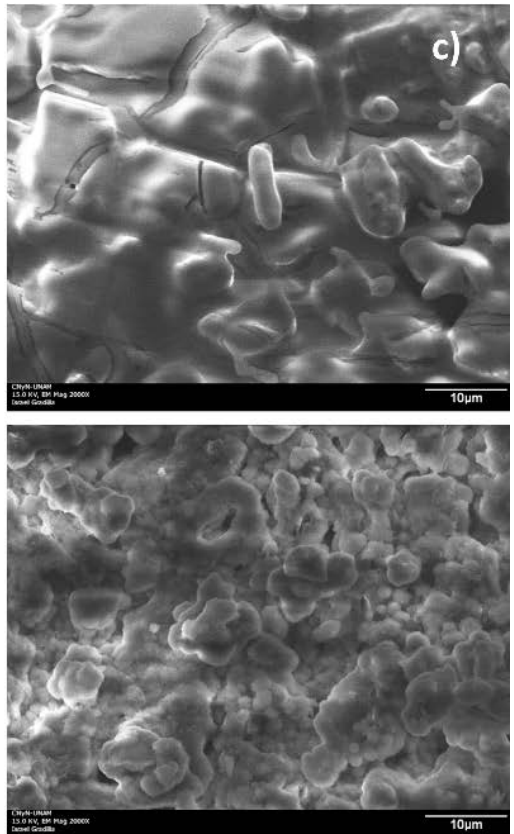

Figure 5. Scanning electron microscopy (SEM) micrographs of natural wollastonite sintered at $1300^{\circ} \mathrm{C}$, pressed at (a) $70 \mathrm{MPa},(\mathrm{b})$ $220 \mathrm{MPa}$ and (c) $500 \mathrm{MPa}$, soaked in SBF solution for 1 and 3 weeks. 
soaking in the SBF solution for several periods of time.

Figure 4 shows the surface of the $\beta$-wollastonite sintered at $1200^{\circ} \mathrm{C}$, pressed at $70 \mathrm{MPa}, 220 \mathrm{MPa}$ and $500 \mathrm{MPa}$ soaked in SBF solution for 0,1 and 3 weeks. The images show how the surface of these sintered materials before immersion exhibit a series of holes and cavities that will serve for the formation of the new layer of apatite. However, as when the pressure was increased from $70 \mathrm{MPa}$ to 220 $\mathrm{MPa}$, a more compact sintered material was obtained; likewise, when the pressure was increased from $220 \mathrm{MPa}$ to $500 \mathrm{MPa}$, a greater compaction in the product sintered was also observed. Nonetheless, for all cases it can be seen how the acicular fibers of the wollastonite were distributed in such a way that holes (pores) can be observed on the surface of the sintered ones, which indicate that these structures are not completely dense. This porosity directly influences the bioactive properties of the materials. This is due to the fact that a certain degree of porosity allows the penetration of the physiological solutions into the interior of the materials, thus making it possible for the growth of the newly formed crystals of the carbonated hydroxyapatite to be produced from the inside towards the surface, resulting in more efficient bioactive properties. This figure also shows the presence of a superficial layer formed by a new material from the first week of immersion. The texture of this layer consist of loosely packed agglomerates presenting a high porosity and a rough surface. By the third week of immersion, the sintered material pressed at $70 \mathrm{MPa}$ shows a significant growth and local agglomerations of this new layer, which is called "newly formed apatite", due to its similarity with the biological apatites formed by the bioactive materials when in contact with physiological fluids. The sintered material pressed at $220 \mathrm{MPa}$ shows a denser and thicker layer with large and deep fractures due to the formation of new particles on the surface of other particles giving rise to the formation of this new layer. On the other hand, the sintered material pressed at $500 \mathrm{MPa}$ presents a very thin layer, depicting several large and deep holes on its surface.

Figure 5 shows the surface of the $\alpha$-wollastonite sintered materials pressed at $70 \mathrm{MPa}, 220 \mathrm{MPa}$ and $500 \mathrm{MPa}$, after soaking for 1 and 3 weeks in the SBF solution. For all cases, a thin layer of newly formed apatite can be seen in the first week, which changes its consistency until forming clusters in the shape of flakes, which consist of small particles accumulated one on top of the other along the surface of the material. This behavior is similar to that observed in poorly soluble bioactive materials such as hydroxyapatite. The different characteristics in the behavior of the formation, as well as in the texture of the layers of newly formed apatite in the sintered materials, indicate that the materials present different bioactivity and biodegradation, which is directly related to its microstructure, surface area and the different phases present in the materials.

Figure 6 and Figure 7 show the X-ray diffraction patterns of the newly formed apatite layers on the surface of the sintered $\beta$-wollastonite and $\alpha$-wollastonite, pressed at the different pressing loads of $70 \mathrm{MPa}, 220 \mathrm{MPa}$ and $500 \mathrm{MPa}$, before 

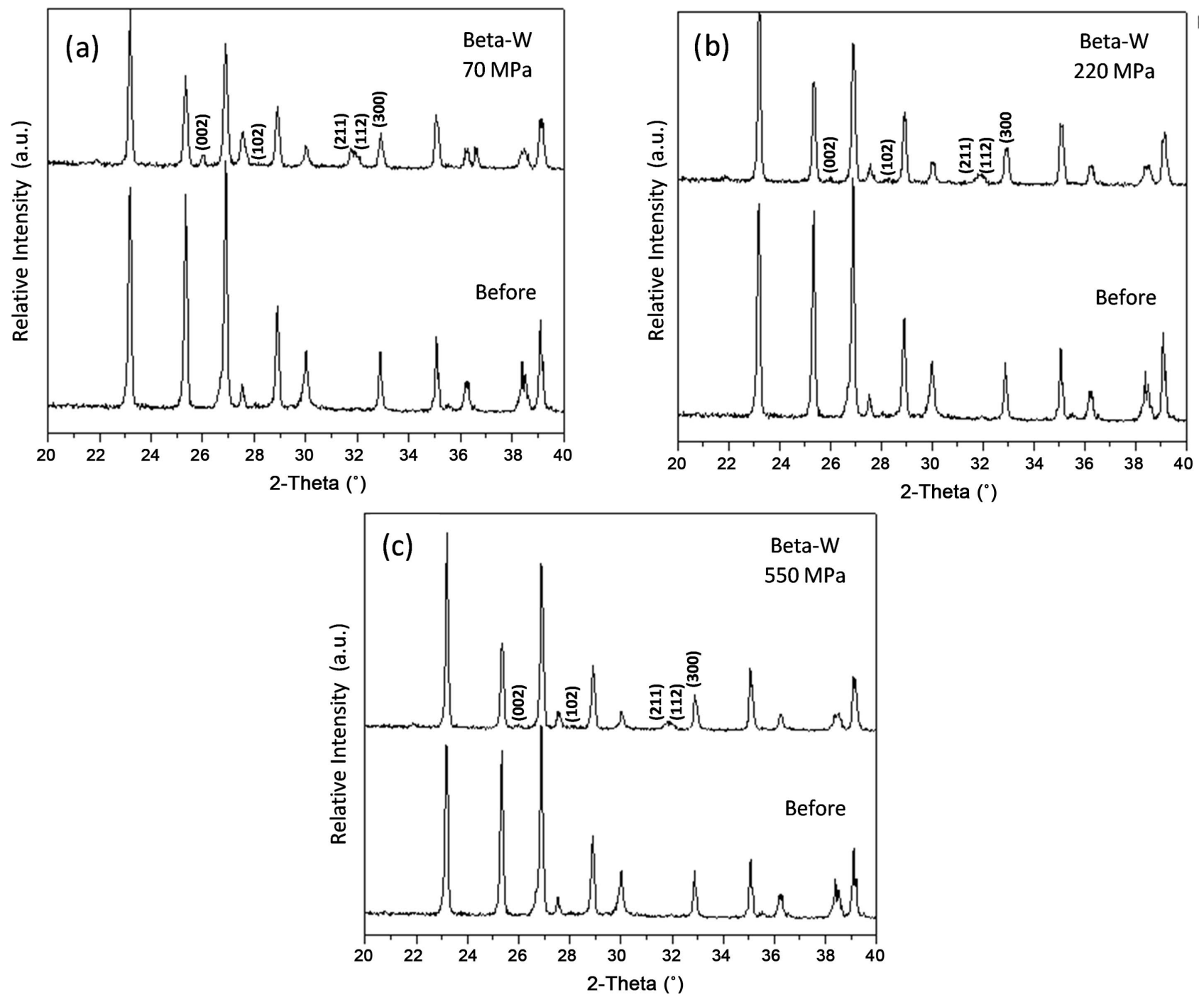

Figure 6. X-ray diffraction patterns for natural wollastonite sintered at $1200^{\circ} \mathrm{C}$, pressed at (a) $70 \mathrm{MPa}$, (b) $220 \mathrm{MPa}$ and (c) 500 $\mathrm{MPa}$, before and after soaking for 3 weeks in SBF solution.

and after immersing for three weeks in the SBF solution. The XRD patterns indicate that the compound formed corresponds to apatite similar to the component formed by the bones. These apatite layers grow in preferential orientations in the XRD patterns manifested by peaks corresponding to the reflection planes (211), (300), (002), (102), and (112). Figure 6 shows that for all sintered materials a slight increase in intensity of the peak at 2 -Theta $=32^{\circ}$ of the plane (211) (characteristic of apatite) is observed, confirming the growth of the newly formed apatite layer. In Figure 7, before soaking, $\alpha$-wollastonite sinters have an intense peak at the same value of 2 -Theta $=32^{\circ}$, similar to the one presented by apatite; the growth is appreciated when observing that the peaks after immersion for 3 weeks in the SBF solution are wider than those observed before the immersion.

\subsection{Evaluation of the Solubility of Wollastonite Sintered Bioceramics}

Figure 8 shows the variation in the concentration of $\mathrm{Ca}, \mathrm{Si}$ and $\mathrm{P}$ as well as the 

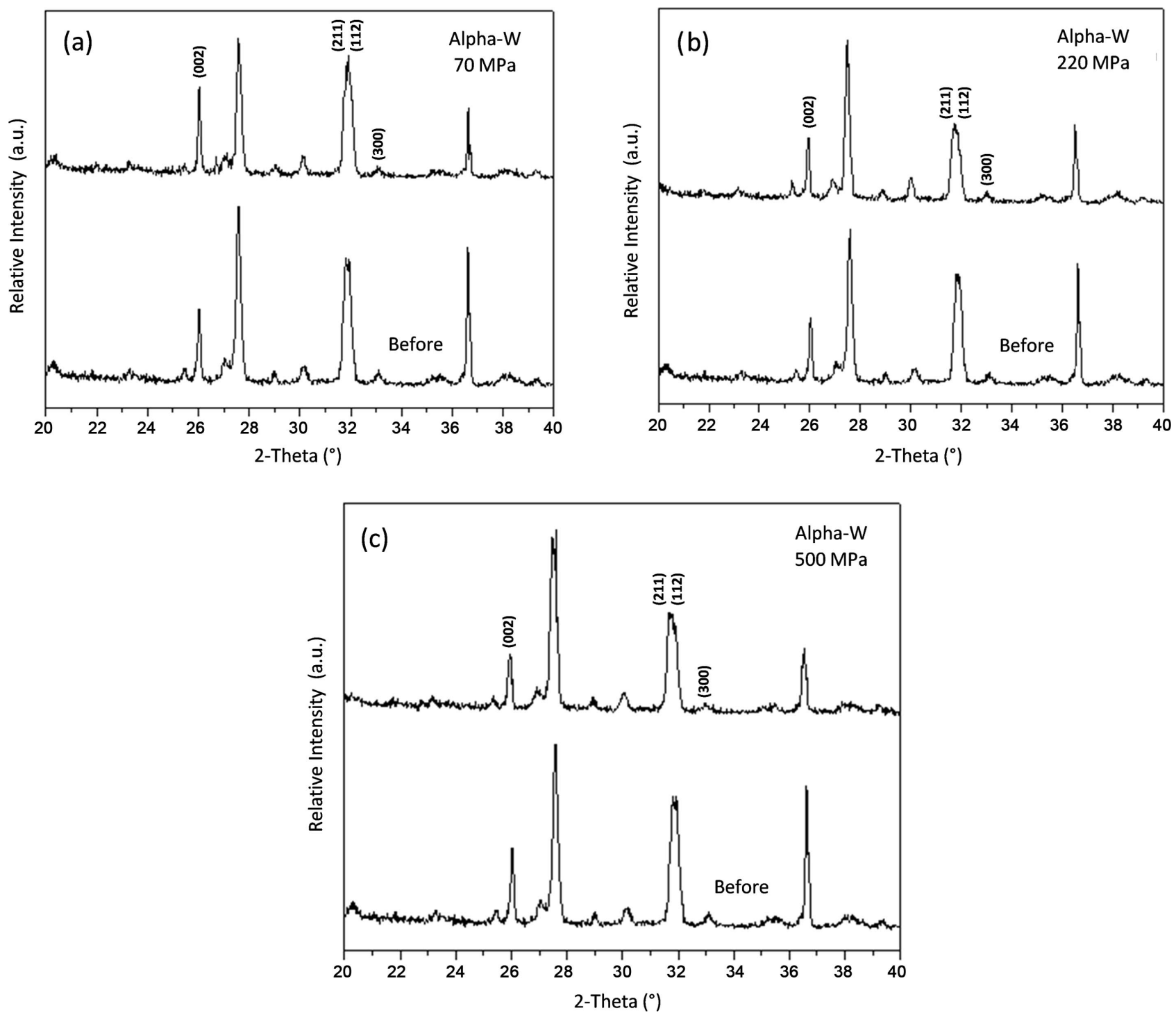

Figure 7. X-ray diffraction patterns for natural wollastonite sintered at $1300^{\circ} \mathrm{C}$, pressed at (a) $70 \mathrm{MPa}$, (b) $220 \mathrm{MPa}$ and (c) 500 $\mathrm{MPa}$, before and after soaking for 3 weeks in SBF solution.

changes in $\mathrm{pH}$ of the SBF solution, as a result of immersion of the sintered materials in this solution for 1, 2 and 3 weeks. These changes are correlated with the bioactivity of these materials.

In the case of the sintered $\beta$-wollastonite pressed at $70 \mathrm{MPa}$, the figure shows a decrease in $\mathrm{P}$ concentration, as well as an increase in $\mathrm{Si}$ concentration, which stabilize at $60 \mathrm{ppm}$. As regards the Ca concentration, it increases significantly to reach $600 \mathrm{ppm}$; also, the $\mathrm{pH}$ values increase to reach a nearly value of 9 . On the other hand, the sintered $\alpha$-wollastonite pressed at $70 \mathrm{MPa}$ presents a similar behavior with respect to $\mathrm{P}$ and $\mathrm{Si}$ concentrations; however, for $\mathrm{Ca}$ concentration, it increases to reach $350 \mathrm{ppm}$ and the $\mathrm{pH}$ does not reach to have values higher than 8. Hereby, a greater solubility of the sintered $\beta$-wollastonite at $70 \mathrm{MPa}$ is observed with respect to the sintered $\alpha$-wollastonite pressed at $70 \mathrm{MPa}$.

The sintered $\beta$-wollastonite pressed at $220 \mathrm{MPa}$ shows an increase in $\mathrm{Si}$ 

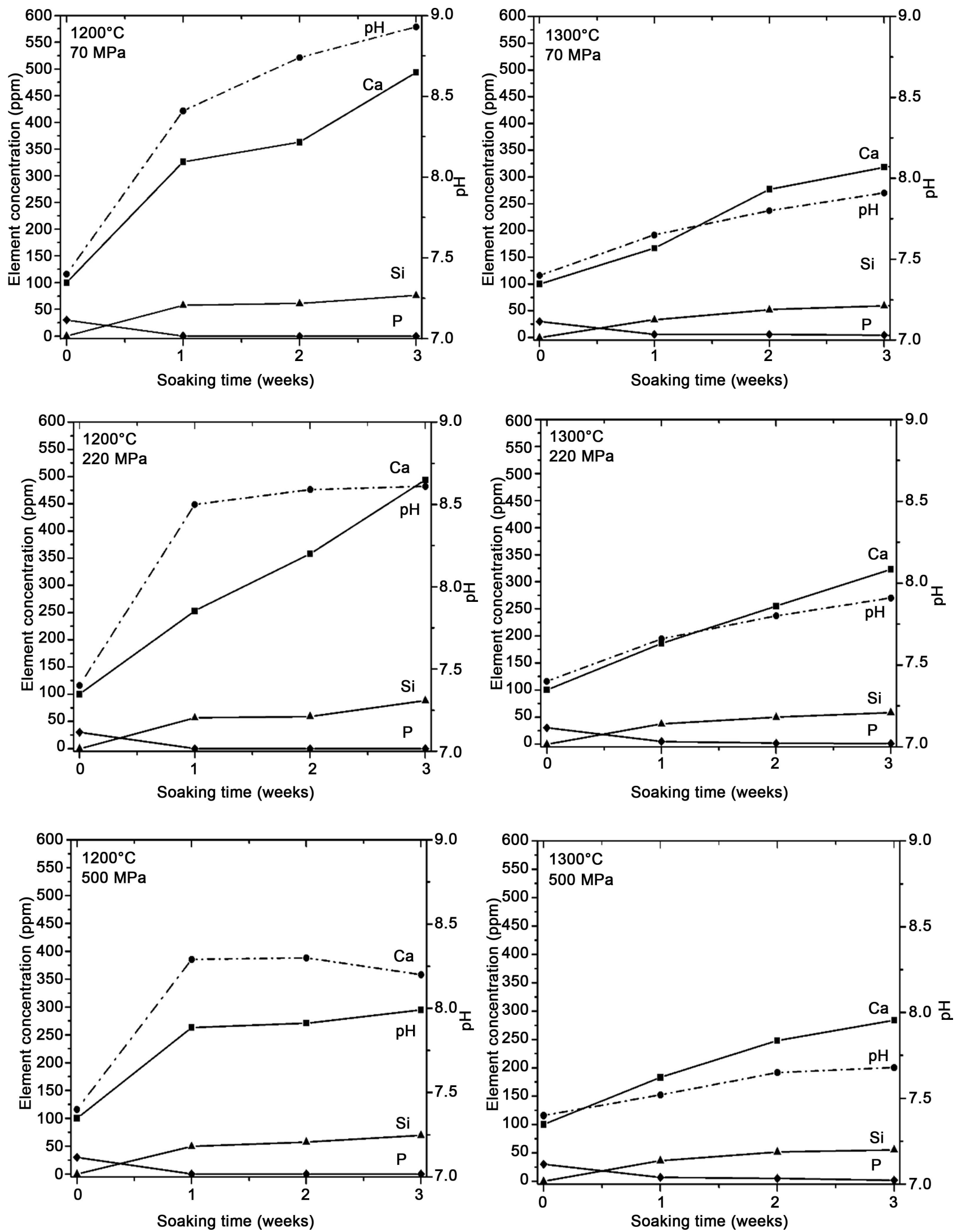

Figure 8. Variation in $\mathrm{Ca}, \mathrm{P}$ and $\mathrm{Si}$ concentration and $\mathrm{pH}$ values of SBF solution, when the natural wollastonite materials, sintered at $1200^{\circ} \mathrm{C}$ and $1300^{\circ} \mathrm{C}$ under different pressing loads: $70 \mathrm{MPa}, 220 \mathrm{MPa}$ and $500 \mathrm{MPa}$, were soaked for 1,2 and 3 weeks in SBF solution. 
concentration, and a decrease in $\mathrm{P}$ concentration, during the period of immersion in SBF solution. With respect to Ca concentration, an increase is observed in the first two weeks until reaching stability during the third week, achieving $460 \mathrm{ppm}$, the $\mathrm{pH}$ increases reaching values higher than 8.6 to then stabilize. The values reached by the sintered $\alpha$-wollastonite pressed at $220 \mathrm{MPa}$ for Ca concentration, reach $300 \mathrm{ppm}$, as well as $\mathrm{pH}$ values lower than 8 . The above reflects a greater solubility in $\beta$-wollastonite in comparison to the sintered $\alpha$-wollastonite pressed at $220 \mathrm{MPa}$.

The sintered $\beta$-wollastonite pressed at $500 \mathrm{MPa}$ shows an increase in the first two weeks for Ca concentration, reaching stability in the third week around 360 $\mathrm{ppm}$. The $\mathrm{pH}$ reaches values of 8 and then stabilizes. The behavior of $\mathrm{P}$ and $\mathrm{Si}$ concentrations is similar to the one observed in the previous sintered materials; a decrease in $\mathrm{P}$ concentration, and an increase in Si concentration until reaching $60 \mathrm{ppm}$. On the other hand, the sintered $\alpha$-wollastonite pressed at $500 \mathrm{MPa}$ reaches values for $\mathrm{Ca}$ concentration around $280 \mathrm{ppm}$ and a $\mathrm{pH}$ of 7.7. The sintered $\beta$-wollastonite pressed at $500 \mathrm{MPa}$ presents a greater solubility with respect to the sintered $\alpha$-wollastonite at the same conditions.

Figure 9 shows the EDS spectra for sintered $\beta$-Wollastonite pressed at 220 $\mathrm{MPa}$ (one of the most soluble materials in this study), before and after soaking for 3 weeks in SBF solution. According to the EDS spectrum before soaking in SBF solution, the elements identified were $\mathrm{Ca}, \mathrm{Si}$ and $\mathrm{O}$, which correspond to the wollastonite. After soaking for 3 weeks in SBF solution the elements identified were $\mathrm{Ca}, \mathrm{P}, \mathrm{O}$ and $\mathrm{C}$, corresponding to a newly formed apatite layer similar to the biological apatites that make up the bone tissue.

These layers were also analyzed by X-ray photoelectron spectroscopy, corroborating the previous results.

\subsection{Mechanism of Formation of Newly Formed Apatite on the Surfaces of Materials}

The dissolution of $\mathrm{Ca}$ ions of the materials into the SBF solution allows an increase in the degree of local supersaturation, causing an increase in the $\mathrm{pH}$ of the solution resulting in the precipitation of apatite through the consumption of $\mathrm{Ca}^{2+}, \mathrm{PO}_{4}^{3-}$ and $\mathrm{OH}^{-}$, which is reflected in a decrease in the concentration of the $\mathrm{P}$ ions of the SBF solution. Although $\mathrm{Ca}$ ions are consumed for the production of the newly formed apatite layer, the dissolution of these ions from the materials is greater than their consumption. Subsequently, the concentration of $\mathrm{Ca}$ and $\mathrm{Si}$ ions continues to increase while the concentration of $\mathrm{P}$ ions continues to decrease, which indicates that this ion is also used for the production of the apatite layer [15] [16].

In wollastonite, the dissolution of $\mathrm{Ca}$ ions is faster than that of $\mathrm{Si}$ ions. The $\mathrm{Ca}$ ions are released into the solution, with which $\mathrm{H}^{+}$ions are exchanged, to form a layer of hydrated silica (that contains $\mathrm{Si}-\mathrm{OH}$ groups) on the wollastonite fiber surfaces. The $\mathrm{Si}-\mathrm{OH}$ groups have been recognized as catalyzing agents for the nucleation and growth of the newly formed apatite layer [15] [16]. 

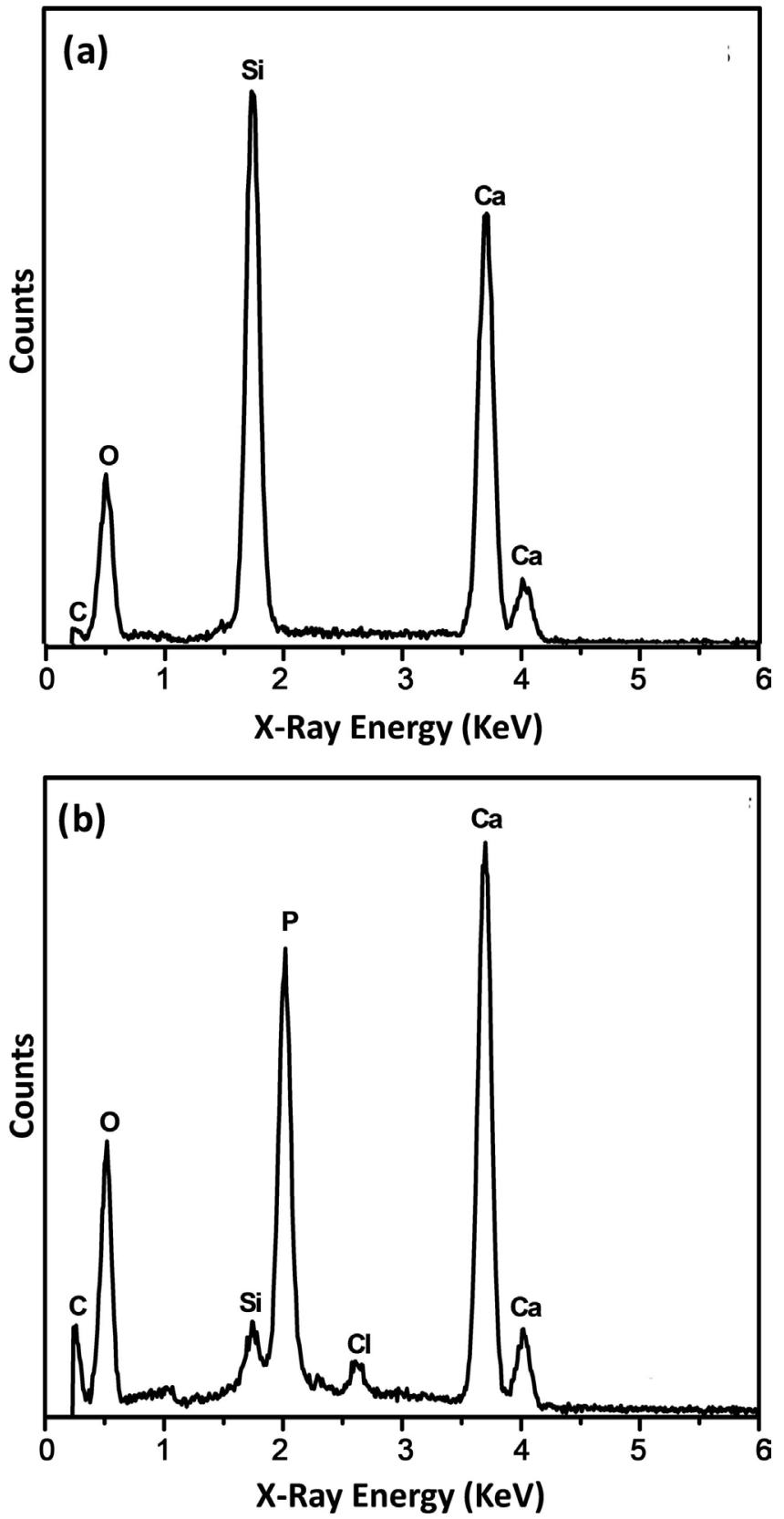

Figure 9. EDS spectra for natural wollastonite materials, sintered at $1200^{\circ} \mathrm{C}$ pressed at $220 \mathrm{MPa}$, (a) before and (b) after soaking for 3 weeks in SBF solution.

The kinetics of this process is directly influenced by the sintering temperatures, resulting in a slower process in materials that are sintered at high temperatures [16].

All the sintered materials showed the ability to form a new layer on their surfaces when coming into contact with the SBF solution, however the different variations in the concentration of $\mathrm{Ca}, \mathrm{P}$ and $\mathrm{Si}$ ions, as well as the $\mathrm{pH}$ behavior of the SBF solution show that during the immersion tests, the surface dissolution of the materials takes place with a simultaneous consumption of $\mathrm{P}$ ions from the solution [16]. 


\section{Conclusion}

The sintered materials of wollastonite present a certain grade of porosity, indicating that in the sintering conditions of this study, the materials produced are not completely dense. This grade of porosity, although minimal, is important to ensure its efficient integration with bone tissue, giving rise to more efficient bioactive properties. The results indicate the presence of two polymorphic phases of wollastonite, the $\beta$-wollastonite and $\alpha$-wollastonite with a transition temperature of the $\beta$ phase to $\alpha$ phase at approximately $1250^{\circ} \mathrm{C}$. The analysis of bioactivity of these materials through their interaction with a simulated body fluid, over several weeks, revealed the formation of a layer of newly formed apatite on their surface. This layer is similar to the biological apatites that make up the bone tissue, which will give rise to the direct union between these materials and the living tissue, once they are implanted in living organisms. The results indicate that the solubility of $\beta$-wollastonite is superior to the solubility of $\alpha$-wollastonite, being the sintered $\beta$-wollastonite pressed at $70 \mathrm{MPa}$, the most soluble material, reaching $600 \mathrm{ppm}$ for $\mathrm{Ca}$ ion and a $\mathrm{pH}$ of almost 9. On the other hand, sintered $\alpha$-wollastonite pressed at $500 \mathrm{MPa}$ was the least soluble material, reaching 280 ppm for Ca ion and a pH of 7.7.

\section{Acknowledgements}

The authors are grateful to Francisco Brown Bojórquez, Víctor Emmanuel Alvarez Montaño from DIPyM-UNISON; Eduardo Antonio Larios Rodríguez from DIQyM-UNISON; Israel Gradilla, Eloisa Aparicio, from CNyN-UNAM for assistance in the characterization and discussions.

\section{References}

[1] Hench, L.L. (1991) Bioceramics: From Concept to Clinic. Journal of the American Ceramic Society, 74, 1487-1510. https://doi.org/10.1111/j.1151-2916.1991.tb07132.x

[2] Ratner, B.D., Hoffman, A.S., Schoen, F.J. and Lemons, J.E. (2004) Biomaterials Science-An Introduction to Materials in Medicine. 2nd Edition. Academic Press, New York, 159-166.

[3] LeGeros, R.Z. (1998) Calcium Phosphate Materials in Restorative Dentistry: A Review. Advances in Dental Research, 2, 164-180. https://doi.org/10.1177/08959374880020011101

[4] LeGeros, R.Z. and LeGeros, J.P. (1993) Dense Hydroxyapatite In: Hench, L.L. and Wilson, J., Ed., An Introduction to Bioceramics, World Scientific, Singapore, 139-180. https://doi.org/10.1142/9789814317351_0009

[5] Bezzi, G., Celotti, G., Landi, E., La Torretta, T.M.G., Sopyan, I. and Tampieri, A. (2003) A Novel Sol-Gel Technique for Hydroxyapatite Preparation. Materials Chemistry and Physics, 78, 816-824. https://doi.org/10.1016/S0254-0584(02)00392-9

[6] Petit, R. (1999) The Use of Hydroxyapatite in Orthopaedic Surgery: A Ten-Year Review. European Journal of Orthopaedic Surgery \& Traumatology, 9, 71-74. https://doi.org/10.1007/BF01695730

[7] López-Acosta, Y., Flores-Castro, K., Ramírez-Cardona, M. and Ortiz-Hernández, 
L.E. (2006) La Wollastonita: Un Mineral no Metálico con Múltiples Aplicaciones. Boletín de la Sociedad Mexicana de Mineralogía, 17, 149-150.

[8] Harabi, A. and Chehlatt, S.J. (2013) Preparation Process of a Highly Resistant Wollastonite Bioceramics Using Local Raw Materials. Journal of Thermal Analysis and Calorimetry, 111, 203-211. https://doi.org/10.1007/s10973-012-2242-5

[9] Ryu, H.-S., J. Lee, K., Kim, H. and Hong, K.S. (2005) New Type of Bioactive Materials: Hydroxyapatite/ $\alpha$-Wollastonite Composites. Journal of Materials Research, 20, 1154-1162. https://doi.org/10.1557/JMR.2005.0144

[10] Obeid, M.M. (2014) Crystallization of Synthetic Wollastonite Prepared from Local Raw Materials. International Journal of Materials and Chemistry, 4, 79-87.

[11] Shukur, M.M., Al-majeed, E.A. and Obeid, M.M. (2014) Characteristic of Wollastonite Synthesized from Local Raw Materials. International Journal of Engineering \& Technology, 4, 426-429.

[12] Yun, Y., Yun, S., Park, H., Lee, Y. and Youn, Y. (2002) Preparation of $\beta$-Wollastonite Glass-Ceramics. Journal of Materials Synthesis and Processing, 10, 205-209.

https://doi.org/10.1023/A:1023074231758

[13] NYCO Minerals Inc. (2001) Premium Quality Wollastonite NYAD M325. NYCOIN-299-04-01 Booklet, NYCO Minerals, Willsboro.

[14] Encinas-Romero, M.A., Aguayo-Salinas, S., Castillo, S.J., Castillón-Barraza, F.F. and Castaño, V.M. (2008) Synthesis and Characterization of Hydroxyapatite-Wollastonite Composite Powders by Sol-Gel Processing. International Journal of Applied Ceramic Technology, 5, 401-411. https://doi.org/10.1111/j.1744-7402.2008.02212.x

[15] Encinas-Romero, M.A., Aguayo-Salinas, S., Valenzuela-García, J.L., Payán, S.R. and Castillón-Barraza, F.F. (2010) Mechanical and Bioactive Behavior of HydroxyapatiteWollastonite Sintered Composites. International Journal of Applied Ceramic Technology, 7, 164-167. https://doi.org/10.1111/j.1744-7402.2009.02377.x

[16] Encinas-Romero, M.A., Peralta-Haley, J., Valenzuela-García1, J.L. and Castillón-Barraza, F.F. (2013) Synthesis and Structural Characterization of Hydroxyapatite-Wollastonite Biocomposites, Produced by an Alternative Sol-Gel Route. Journal of Biomaterials and Nanobiotechnology, 4, 327-333.

[17] Kokubo, T. and Takadama, H. (2006) How Useful Is SBF in Predicting in Vivo Bone Bioactivity? Biomaterials, 27, 2907-2915.

https://doi.org/10.1016/j.biomaterials.2006.01.017 